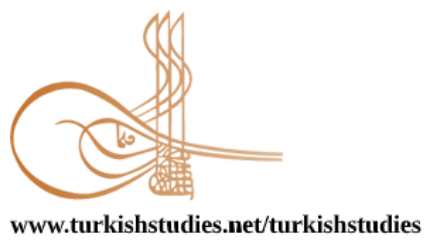

www.turkishstudies.net/turkishstudies
Turkish Studies

eISSN: $1308-2140$

Research Article / Araştırma Makalesi

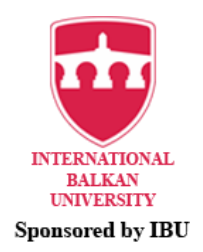

Sponsored by IBU

\title{
Yönetimde Merkezileşmenin Bir Etkeni Olarak Salgınlar
}

\author{
Epidemics as a Factor of Centralization in Government
}

\author{
Aziz Küçük*
}

\begin{abstract}
Epidemics that cause mass death of people in all periods of history are the silent enemies of national health, safety and welfare. Although the management of epidemic diseases is perceived as a medical phenomenon, it is obvious that it will not be successful unless it is supported by continuous and restrictive measures. Taking necessary precautions against epidemics, that became widespread especially in the 19th century with the development of capitalist market relations and threatened the existence of political power, has become the main priority of the modern state. Measures taken to protect the health of the population within this rationality, especially quarantine practices, have led to the strengthening of centralization and the establishment of health organizations. This study examines to how grew the state's political power in the period of epidemics that disturbing social order, from a historical perspective through the example of the UK, USA and Turkey, with a focus on Germany. Even in states such as the USA and the UK, where atomistic individualism based on neoliberal political thought and minimal state understanding are prevalent, centralization tendencies dominate during such crisis eras. In this context, it is argued in the study that epidemics are one of the leading factor that trigger centralization tendencies in government. The coronavirus epidemic has depicted that the state has mechanisms to use social control and surveillance more than ever, with the capabilities of digital technologies (such as smartphones, artificial intelligence-assisted software, taking temperature with drone, data analytics) to combat the virus. At the same time, the epidemic reinforced the view that health care is not a cost component, but a prerequisite of public welfare and an investment that contributes to economic growth.
\end{abstract}

Structured Abstract: The spreading of Coronavirus throughout the world and its becoming an pandemic have caused a total public intervention and have led to the questioning of health systems and, in a broader context, the political systems. In Covid-19 pandemic, some countries in Continental Europe (such as Germany and Austria) have achieved relatively successful results compared to other countries, and even opened museums in the early period and started football matches. This brought the question of whether the state tradition played a role in this success. Similarly, the question of whether the unitary state is more effective in dealing with the epidemic, unlike the federal systems, has also led to a renegotiation of the basic principles that shape political systems. On the other hand, some scholars have suggested that neoliberal policies in the field of health have weakened their capacity to respond to coronavirus pandemic in many countries on both sides of the North Atlantic, particularly in Italy, Spain and the USA.

\footnotetext{
${ }^{*}$ Dr., T.C. Sağlık Bakanlı̆̆

PhD, Republic of Turkey, Ministry of Health..

ORCID 0000-0002-1296-4726

aziz.kucuk@yahoo.com

Cite as/ Atıf: Küçük, A. (2020). Yönetimde merkezileşmenin bir etkeni olarak salgınlar. Turkish Studies, 15(4), 703-

721. https://dx.doi.org/10.7827/TurkishStudies.44281

Received/Geliş: 16 June/Haziran 2020

Accepted/Kabul: 10 August/Ağustos 2020

Copyright $(\mathrm{C}$ MDE, Turkey

Checked by plagiarism software

Published/Yayın: 30 August/Ağustos 2020

CC BY-NC 4.0
} 
Although the form and methods of its formation differ historically by country, the establishment of centralization processes rests on socio-economic dynamics. While central government has been shaped as an extension of capitalism, capitalist development has led to an even stronger centralization. The fact that the health of the population, which is located at the intersection of the requirements of capitalism and the idea of centralization, is the main area that states take under control in order to ensure the continuity. Centralization tendencies are observed to get stronger when it comes to the health of the nation as a whole, especially during the epidemic periods such as cholera, typhoid, plague, and influenza in the history, and coronavirus pandemic as of today. In this context, the study examines to how grew the state's political power in the period of epidemics that disturbing social order, from a historical perspective through the example of the UK, USA and Turkey, with a focus on Germany. In the study is argued that epidemics are one of the leading factor that trigger centralization tendencies in government.

The emergence of small princely states in Central Europe, especially in German-speaking lands, after Thirty Years' of Wars (1618-1648), influenced their centralization tendencies and practices. On the other hand, Cameralism, which is the by-product of this idea, has sought to increase the productive capacity of the population on the basis of the "police state" idea for the sake of the welfare and health of the public. To reduce the impact of the destruction caused by war and epidemics, Cameralist thinkers such as Johann Peter Frank, Wolfgang Thomas Rau, Von Justi and Sonnenfels introduced the idea of "medical police". This idea, which is especially popular in Germany and Austria, served to strengthen the political power and ensure social order through sanitary reforms, especially in quarantine practices.

Epidemic diseases and public health problems started to become widespread in the UK due to increasing industrialization and rapid urbanization since the end of the 18th century. Cholera epidemics, which started to increase in many cities, especially in London, triggered the intervention of the central government and regulations in the field of public health in the Victorian Britain. After the first public health law was adopted in 1848, the local governments' practices that were optional at the beginning became eventually compulsory.

The development of public health in the USA did not follow the same characteristics as the UK. Reform efforts regarding the public health in the USA were supported by local voluntary and Puritan moral codes. Increased epidemic diseases constituted the breakdown in the understanding of central government that individual rights would harm absolute sovereignty. After the American Civil War (1861-1865), public health reform, primarily quarantine practices, along with centralization processes, began to be implemented at both the state and federal government levels.

As in other countries, one of the factors that stimulated the modernization and centralization efforts of the state both in the 19th century Ottoman State and in the Early Republican Period was the policy of combating infectious and epidemic diseases. As a result of the institutionalization efforts that started after the cholera epidemic in Istanbul in 1831, the Quarantine Council (Karantina Meclisi or Meclis-i Umur-1 Sihhiye) was established in 1838. The opening of the Military College of Medicine (Tiphane-i Amire), regulations regarding infectious diseases, and sending students to Europe are also innovations that bear centralist nature. In the early Republican period, medical topography studies, establishment of the Institute and School of Hygiene (T.C. Merkez Hıfzıssıhha Müessesesi), combating malaria and syphilis, and finally the Public Health Law No. 1593 (1593 sayılı Umumi Hıfzıssıhha Kanunu) are sanitary reform movements that aim to realize the centralization and the fabrication of social order.

Today, the health-oriented "national security" problem triggered by the coronavirus pandemic were effective in minimizing the external costs of the epidemic with the ability of central government to act rationally and organized. The coronavirus pandemic may lead to a change in the public health perspective of the states in the new period, and the increase in R\&D-oriented social investment expenditures, particularly in the field of health, such as pharmaceuticals, vaccines, protective equipment, and medical devices. It can be suggested that the demand for monopolization of social investment functions may lead to a new type of centralization in the continuation of this trend.

Keywords: Epidemics, modern state, centralization, quarantine practices, coronavirus.

Öz: Salgın hastalıklar, tarihin her döneminde insanların kitleler halinde ölümüne yol açmış ve ulusal sağlığın, güvenliğin ve refahın sessiz düşmanları olmuşlardır. Salgın hastalıkların yönetimi tıbbi bir olgu gibi algılansa da, sürekli ve kısıtlayıcı tedbirlerle desteklenmedikçe başarılı olamayacağı aşikârdır. Özellikle 19. yüzyılda 
kapitalist pazar ilişkilerinin gelişmesi ile yaygınlaşan ve siyasal iktidarın varlığını tehdit eden salgınlara karşı gerekli önlemlerin alınması, modern devletin temel önceliği haline gelmiştir. Bu rasyonalite çerçevesinde karantina uygulamaları başta olmak üzere nüfusun sağlı̆ııı korumaya yönelik tedbirler, merkezileşmenin güçlenmesine ve sağlık teşkilatlarının kurulmasına öncülük etmiştir. Bu çalışma, toplumsal düzenin bozulduğu salgın dönemlerinde devletin siyasal iktidarının nasıl büyüdüğünü tarihsel bir perspektifle Almanya eksenli olarak Kıta Avrupası, İngiltere, ABD ve Türkiye örnekleri üzerinden incelemektedir. Neoliberal politik düşünceye dayalı atomistik bireycilik ve minimal devlet anlayışının hâkim olduğu ABD ve İngiltere gibi devletlerde bile bu tür kriz dönemlerinde merkezileşme eğilimlerinin ağır bastığı görülmektedir. Bu bağlamda çalışmada, yönetimde merkezileşme eğilimlerini tetikleyen etkenlerin başında salgınların geldiği ileri sürülmektedir. Koronavirüs salgını, devletin virüsle mücadelede dijital teknolojilerin verdiği imkânlarla (akıllı telefonlar, yapay zekâ destekli yazılımlar, dronlarla ateş ölçme, veri analitiği gibi) toplumsal kontrol ve gözetim işlevini her zamankinden fazla kullanabilecek mekanizmalara sahip olduğunu göstermiştir. Aynı zamanda salgın, sağlık hizmetlerinin bir maliyet unsuru değil, kamusal refahın bir önkoşulu ve ekonomik büyümeye katkıda bulunan bir yatırım olduğu görüşünü perçinlemiştir.

Anahtar Kelimeler: Salgınlar, modern devlet, merkezileşme, karantina uygulamaları, koronavirüs.

\section{Giriş}

Dünya genelinde koronavirüsün yayılarak pandemi haline gelmesi, topyekûn bir kamusal müdahaleyi zorunlu kılmış ve sağlık sistemlerinin daha geniş bağlamda ise politik sistemlerin sorgulanmasına neden olmuştur. Covid-19 pandemisinde Kıta Avrupa'sında bazı ülkelerin (Almanya, Avusturya gibi) nispeten diğer ülkelere göre başarılı sonuç elde etmeleri hatta erken dönemde müzeleri açmaları ve futbol müsabakalarını bașlatmaları (New York Times, 13/05/2020) devlet geleneğinin bu başarıda rolü olup almadığı sorusunu akıllara getirmiştir. Benzer şekilde üniter devletin, federal sistemlerin aksine pandemi ile başa çıkmak için daha uygun olup olmadığı? sorusu da siyasal sistemleri biçimlendiren temel ilkelerin yeniden tartışılmasına yol açmıştır. Bu soru genel olarak merkezi üniter bir devletin hızlı ve koordineli eylemde bulunma yeteneği ile bölgesel/yerel yönetimlerin, yerel halkın ortak ihtiyaçlarını karşılayan önlemler alma yeteneği arasında bir tercih durumunu ortaya koymaktadır.

Merkezi devletlerin hızlı hareket edebilme yeteneği, bulaşıcılığın erken evresinde salgın hastalığın kontrol altına alınmasında özel önem taşımaktadır. Üniter devletlerde merkezi yönetim, harekete geçmek için farklı bölgelerdeki tüm otoritelerin fikir birliğine varmasına gereksinim duymaz. Örneğin Güney Kore'de merkezi yönetim sadece test yapılmasını öncelikli hale getirmekle kalmadı, aynı zamanda testi pozitif çıkanları kontrol altında tutmak ve karantinaya uymalarını sağlamak için cep telefonu ve kredi kartı bilgilerini de kullanmıştır (Lizardo, 2020). Tarihsel olarak, salgınlar esnasında devlet müdahalesinin artmasının bir diğer kanıtı, yerel otoritelerin kararlarının diğer yerleri etkileyen olumsuz dışsallıklara sahip olabilmesidir (Higgs, 1987: 9-10). Nitekim hastalığın kendi bölgesine girişini engelleyemeyen bir yerel yönetim, hastalıkların diğer şehirlere yayılma olasılığını artırır (Luckett ve Gray, 1925: 133). Bu durumda bir bütün olarak ulusun sağlığı, yerel yönetimlerin eylemlerinin veya eylemsizliğinin sonuçlarına bağlı olmamalıdır. Dolayısıyla salgın hastalıkların yarattığı dışsal maliyet nedeniyle merkezi yönetim, sahip olduğu araçlarla ulusun çıkarlarını daha iyi temsil edebilir. Örneğin merkezi bir yönetim, yerel yönetimlerin aksine daha rasyonel ve organize hareket ederek ulusal karantina tedbirleri uygulayabilir veya tıbbi ihtiyaçların (malzeme, ilaç, tanı kiti gibi) tedarik edilmesi sürecini güvence altına alabilir.

Bununla birlikte, bazı durumlarda artan merkezileşme hızlı karar vermeyi kolaylaştırmak yerine zorlaştırabilir. Yerel yönetimlerin esnekliği ve yerel laboratuvarlarla yakın ilişkileri Almanya'nın diğer ülkelerden daha erken test yapmaya başlamasına olanak sağlamıştır (Lizardo, 2020). Eğer merkezi yönetim bu tedbirleri almakta geç veya yetersiz kalmışsa yerel yönetimlerin sahip olduğu özerkliğin yarattığı esneklik ona avantaj sağlayabilir. Brezilya Devlet Başkanı Jair Bolsonaro, Covid-19'u 'küçük bir grip' olarak nitelendirerek sosyal izolasyon tedbirlerine karş1 
çıkmış ve ülkesinde karantina ilan eden valileri eleştirmişti. Ancak eyalet valilerinin neredeyse tamamı Dünya Sağlık Örgütü tedbirlerini uygulamaya devam etmiştir (hurriyet.com.tr, 2020). Benzer şekilde, İsviçre'deki bazı kantonlar karantina tedbirlerini federal yönetimin aldığı önlemlerden daha fazla genişletmiştir. ABD'de New York Valisi Cuomo'nun, Başkan Trump'la New York'un durumunun ciddiyeti ve eyaletlerin krizi yatıştırma çabalarının desteklenmesinde federal yönetimin rolü üzerine sürekli siyasal çekişmeleri (Weible vd. 2020: 230) de tarihsel olarak federatif sistemlerdeki tartışmaların bir izdüşümü niteliğindedir.

Koronavirüs salgının gündeme getirdiği konulardan biri de neoliberal politikaların temel öğelerinden biri olan ve uluslararası örgütler tarafından özendirilen sağlık hizmetlerinin piyasalaştırılması ve metalaştırılması süreçlerinde önemli stratejik araçlardan biri olan (Lister, 2008: 122) yerelleşme politikasıdır. Özellikle Dünya Bankası tarafından 1980 sonrası yapısal uyum programları ile idari yerelleşme deconsantration, devolution, delegation ve privatization şeklinde kamu sektörü reformu bağlamında ülkelere sıkl1kla önerilmiştir (Küçük, 2018a: 177-181). Bu bağlamda Navarro (2020: 271-275) ve Peters (2020) İtalya, İspanya ve ABD başta olmak üzere Kuzey Atlantik'in her iki tarafındaki birçok ülkede sağlık alanındaki neoliberal politikaların (kemer sıkma önlemleri, yerelleştirme ve sağ lik hizmetlerinin özelleştirilmesi gibi) koronavirüs pandemisine yanıt kapasitesini zayıflattığını ileri sürmüştür.

Tarihsel olarak ülkelere göre oluşma biçimi ve yöntemleri farklı, biçimlenişleri değişiklik gösterse de merkezileşme süreçlerinin oluşumu, sosyo-ekonomik dinamikler üzerine oturmaktadır. Merkezi yönetim kapitalizmin bir uzantısı olarak şekillenirken, kapitalist gelişme beraberinde merkezileşmenin daha da güçlenmesine yol açmıştır (Önen ve Reyhan, 2011: 15-16). Kapitalizmin gereklilikleri ile merkezileşmenin tarihselliğinin arakesitinde yer alan nüfusun sağlığı olgusu ise, devletlerin sürekliliğinin sağlanabilmesi adına kontrol altına aldıkları en önemli alanların başında gelmektedir. Özellikle geçmişte kolera, tifo, veba, grip gibi salgın dönemlerinde günümüzde ise koronavirüs pandemisinde yaşandığı şekliyle bir bütün olarak ulusun sağlığı söz konusu olduğunda, merkezileşme eğilimleri güçlenmektedir. $\mathrm{Bu}$ bağlamda çalışmada, yönetimde merkezileşme eğilimlerini tetikleyen etkenlerin başında salgınların geldiği ileri sürülmektedir. Toplumsal düzenin bozulduğu salgın dönemlerinde devletin gücünün/iktidarının nasıl büyüdügünün analizi Almanya eksenli olarak tarihsel bir perspektifle Kıta Avrupası, İngiltere, ABD ve Türkiye örnekleri üzerinden gösterilmeye çalışılacaktır.

\section{Kavramsal Çerçeve: Salgınlar ve Merkezileșme}

Bir salgın, hastalığın özel bir biçiminden daha fazlasıdır. Değişmez özellikleriyle aynı anda birçok insana bulaşan hastalıklara salgın hastalıklar denilmektedir. Böyle olunca kişisel hastalıklarla salgın olgusu arasında doğa ya da tür farkı olmayıp, salt matematiksel bir eşik sorunu vardır. Yani bir salgının olması için ayrı ayrı kişilerde görülen bir hastalığın çok sayıda kişide aynı anda ortaya çıkması yeterlidir. Bulaşma, sadece salgının kitlesel gerçekliğinin bir biçimidir. Bulaşıcı olsun ya da olmasın salgın bir tür tarihselliğe sahiptir; bundan dolayı onunla baş etmek için karmaşık bir gözlem metodu kullanmak zorunludur. Olağandışı, rastlantısal, beklenmedik özellikleri ile tanımlanan ve kolektif bir olgu olan salgın, çoklu bir bakış açısı ve kendine özgü bir süreç gerektirir (Foucault, 1973: 23-25). Pandemi ise çok geniş bir coğrafik ölçekte, belki de dünya çapında ya da en azından dünyanın birçok bölgesini etkileyen salgındır (Hays, 2005: xi).

Sınır tanımayan özelliği ile salgın hastalıklar, dünya genelinde ulusal sağlığın, ekonomik büyümenin ve istikrarın da sessiz düşmanlarıdır. Bireysel, ulusal ve küresel güvenliği tehdit eden salgın hastalıklar, tarihsel süreçte çok sayıda ölüme ve toplumsal soruna yol açmıştır. Tarihte görülen ilk salgınların başında MÖ 430-427 yılları arasında Atina'da görülen salgın gelmektedir. Mısır'dan liman kenti Pire'ye geldiği varsayılan ve oradan Atina'ya yayılan salgın MÖ 431'de başlayan Atina ve Sparta şehir devletleri arasındaki Peloponez Savaşı'nın başında meydana geldiği söylenmekle birlikte, nedeni (çiçek hastalığı mı?, veba mı?, kızamık mı?) tam olarak belirsizliğini korumaktadır 
(Longrigg, 1992: 21-26). Eski Roma'da görülen sitma ile Mezopotamya bölgesinden dönen Roma askerleri arasında MS 165 yılında başlayan Antoninus Vebası olarak adlandırılan salgın da binlerce kişinin ölümüne sebebiyet vermiştir. İlk veba pandemisi ise MS 541'de Akdeniz'e komşu ülkelerde (Mısır, Filistin, Tunus, İtalya) ortaya çıkmış ve 749 yılına kadar 17 dalga şeklinde görülmüştür (Hays, 2005: 9-31). 1380 yılından beri periyodik olarak veba salgınlarına maruz kalan Venedik, Sicilya, Cenova gibi İtalyan şehir devletlerinde 1630'lardaki ikinci veba pandemisi de çok sayıda insanın ölümüne neden olmuştur. Bununla birlikte, İtalyan şehir devletleri veba tehdidine yanıt olarak karmaşık ve sofistike yönetim mekanizmaları geliştirmiş ve kapsamlı halk sağlığı düzenlemeleri yaparak kamusal önlemler almışlardır (Pullan, 1992: 101-107; Hays, 2005: 103-105). 19. yüzyılda etkili olan kolera ve veba salgınları ise Asya'dan özellikle de Hindistan bölgesinden Yakın Doğu'ya oradan Avrupa ve Amerika kıtasına yayılmıştır. Genellikle gemilerle deniz yoluyla olan yayılım kervan ticareti, haç ziyaretleri ve savaşların etkisiyle kara yoluyla da bulaş göstermiş̧tir (Sarıyıldız, 1989: 2-6). Bu nedenle bulaşmayı kontrol altına alma düşüncesinin, bir başka ifade ile "hijyenik ortam yaratma hayali"nin modern Batı tarihine ve kültürüne damga vurduğu (Bashford ve Hooker, 2001: 2) söylenebilir.

Bir salgını kontrol altına almak için, ulusun sahip olması gereken 'tıbbi bilinç', bilgi, denetim ve kısıtlama (zorlama) içeren 'siyasal bilinç' ile desteklenmelidir. Bir başka deyişle, bulaşıcı hastalıkların bildirimi, yönetimi tıbbi bir olgu gibi algılansa da bu çabalar, sürekli ve kısıtlayıcı müdahalelerle desteklenmedikçe tam anlamıyla başarılı olamaz. Bir kamu gücü tarafindan desteklenirse bir salgın tıbbı var olabilir. Kamunun refahı ve sağlığı için madenlerin, mezarlıkların, gıda üretiminin kontrolü, eğitim kurumlarının ve hapishanelerin sıhhi koşullarının düzenlenmesi, sağlıksı konutların yasaklanması gibi her türlü önlemin alınması ve bu amaçla kişilerin hak ve özgürlüklerine müdahale edilebilmesi devlet iktidarının varlığını gerektirir (Foucault, 1973: 25-27). $\mathrm{Bu}$ rasyonalite, aynı zamanda kapitalist ekonomi ile tamamlayıcılık ilişkisi göstererek, ekonomik yapının bütünlüğünü korumaya yönelik bir kalkan işlevi görmeye yöneliktir. İngiliz, Fransız veya ABD merkezileşmesinin temel gerekçesi olan bu durum (Önen ve Reyhan, 2011: 53-54), ekonomik yapının bütünlüğünü tehdit eden salgınlara karşı gerekli önlemlerin alınması zorunluluğunu doğurmuş ve bu zorunluluk giderek merkezileşmeyi daha fazla tetikleyerek güçlendirmiştir. Çünkü tekrarlayan kolera salgınlarının neden olduğu sosyo-ekonomik ve psikolojik kaygılar, politik sistemin özgürlükçü-otoriter tartışmalarını geri plana iterek devlet kurumları tarafından hızla müdahale edilmesini gerektirmiştir (McNeill, 1976: 239-240). Bu nedenle salgın hastalıklar ${ }^{1}$, nüfusun sağlığı sorununu modern devletin ortaya çıkışından bu yana (19. yüzyıldan sonra daha fazla hissedilse de) politik gündemin en üst noktasına taşımış ve sanayi toplumlarında düzenin bozulmasının belirgin bir sembolü haline gelmiştir. Bunun bir sonucu olarak da, politik ve ekonomik düşüncede halk sağlığının önem kazanması, merkezileşme eğiliminin yükselişi ile aynı zaman aralığında ve birbirleriyle bağlantılı gerçekleşmiştir.

\section{Salgınlar ve Modern Devlet İlişskisi}

Modern devlet 16. yüzyılın sonlarından itibaren ortaya çıkmaya başladığında, ulusal sağlıkla ilgili yeni fikirler yavaş yavaş önem kazanmaya başlamıştır. Modern devletin gelişimi ile nüfusun sağlığı arasında güçlü bir ilişki vardır. Nitekim Corrigan ve Sayer, İngiliz devletinin oluşumunda

\footnotetext{
${ }^{1}$ Salgın hastalıklar, daha sonraki dönemlerde birçok yazar tarafindan toplumsal uyumun analizi için kullanılan bir inceleme nesnesi haline gelmiştir. Özellikle 19. yüzyıl kolera salgınları üzerinden yapılan çalı̧̧maların birçoğu, pandemi dalgaları ile devrimci isyanlar arasındaki bağlantıyı göstermeye çalışmıştır (McNeill, 1976: 57-61). Avrupa kıtasında 1830, 1848, 1854, 1866 yıllarında görülen kolera salgınları sonrası İngiltere, Fransa, Almanya gibi ülkelerde rejim değişikliğine yol açan devrimlerin ortaya çıkması veya toplumsal karıșıklıkların yaşanması buna delil olarak gösterilmiștir (Evans, 1990: 285-290). Bazı yazarlar ise koleranın Avrupa ve Amerika'da halk sağlığı yönetiminin gelişimini ve kurumsallaşmasını teşvik ettiğini, yeni sağlık teşkilatlarının oluşturulmasında katalizör rolü oynadığını kanıtlamaya çalışmışlardır (McNeill, 1976: 239-240; Porter, 1999). Bununla birlikte, Ranger ve Slack (1992: 5-7) bu görüşe karş1 çıkarak halk sağlı̆̆1 yönetiminin gelişimine bir dizi salgın olayının (kolera, humma, veba gibi) bir araya gelmesinin yol açtığını ileri sürmüştür.
} 
devlet formasyonu olan ulusal ilerleme sistemini harekete geçiren üç büyük fikri; "istatistik", "eğitim" ve "sağllk (hijyen)" düşüncesi olarak değerlendirmektedir (Aktaran Neocleous, 2014: 56). $\mathrm{Bu}$ üç fikrin bir araya gelmesi ve ortak bir amaç doğrultusunda kullanılması, toplumsal bedenin devlet tarafindan yönetilmesinin araçsallığını oluşturmuştur. Bu planlı girişimin bir neticesi olarak, erken modern dönemde nüfusun sayısı ve sağlığı ile ilgili bilgileri elde etmek için çeşitli yöntemler kullanılmıştır. 16. yüzyılda İtalyan şehir devletlerinde nüfus, ekonomik faaliyet ve salgın hastalıklar hakkında ayrıntılı istatistiksel araştırmalar yapılmıştır. 18. yüzyılda İsveç’te doğumlar, ölümler, ölüm nedenleri, okuryazarlık düzeyleri ile sağlıksızlık belirtileri hakkında bilgiler toplanmıştır. Fransa' da Napolyon döneminde bir istatistik bürosu kurulmuştur. Çünkü hükümdarlar, devletin gücünü/iktidarını hesaplamak ve genişletmek için sürekli bilgiye ihtiyaç duymaktaydı (Porter, 1999: 48). Nüfusu sayarak devletin gücünü değerlendirme yöntemleri 17. yüzyılın sonlarında hekim, varlıklı bir toprak sahibi ve erken dönem bir sosyal bilimci olan William Petty (1623-1687) tarafından geliştirilmiştir. İrlanda Siyasi Anatomisi adlı kitabının önsözünde Francis Bacon'un siyasi beden ile doğal bedenin korunmasının bağlantılı olduğu ve devletin gücünün istatistiksel olarak parçalara ayrılıp incelenebileceği (anatomi gibi) gözleminden ilham aldığını ileri sürmüştür. Petty, devletin askeri savunma, ticari ve teknolojik genişleme ve sosyal reform firsatlarını güçlendirmek için toplumsal olguların politik bir aritmetiğini üretti. Bunun için nüfus, ticaret, üretim, eğitim, hastalıklar ve gelir hakkında veri topladı. Petty'nin bir arkadaşı olan John Graunt (1620-1674) da sağlık ve hastalık kayıtlarını incelemeye başladı. Londra Ölüm Kayıtlarını inceleyen Graunt, doğumlar ve ölümler gibi yaşam olaylarının düzenliliğini - erkeklerin kadın doğumlarından fazla ve erkeklerin kadın ölümlerine göre fazla olduğunu, kentlerde ölüm oranlarının daha yüksek olduğunu keşfetmiştir (Porter, 1999: 49). İngilizler toplumsal istatistiklerin kullanımını geliştirmesine rağmen, modern ulus-devletin doğası gereği istatistiklerle karakterize edilmesi 18. yüzyıl Alman devletlerinde, öncelikle de Prusya'da gerçekleşmiştir. Doğadaki ilahi düzenin sürekliliğini göstermek için J.P. Süssmilch, 1740'ta evlilik yaşları, doğum oranları, nüfus artışı, tarım arazilerinin durumu ve kullanımı arasındaki ilişkiyi gösteren sistematik bir yaklaşım geliştirmiştir. Foucault (1990: 140) bireysel ve toplumsal bedene giderek daha fazla disipline edici müdahaleleri kolaylaştıran çizelgeler geliştiren Süssmilch'in 18. yüzyılın sonunda ve 19. yüzyılın başında büyüyen biyo-siyaset bilimini temsil ettiğini ileri sürmüştür. Bütün bunlar, 19. yüzyılda sistematik hastalıkların önlenmesi için bir ön koşul haline gelecek olan biyoistatistiğin ve epidemiyolojinin ilk temelleriydi.

Olasılık hesaplamaları ve nüfusun erken modern keşfi, halk sağlığının gelişimi üzerinde güçlü bir etkiye sahip olmuştur. İstatistikler, nüfusun sağlık ve hastalık profilini araştırmak, kamusal hijyen tedbirleri almak için gerekli yöntemleri sağlamıştır. Devleti yönetme sanatının bir bileşeni haline gelen istatistiki bilgi, salgınlar söz konusu olduğunda daha da hayati bir hal almıştır. Bu bağlamda modern devletin merkeziyetçi iktidar araçlarından biri de tıbbi coğrafya çalışmalarıdır. En basit şekliyle coğrafi metot ve teknikleri tıbbi sorunlara uygulamak olan tıbbi coğrafya, özellikle 18. yüzyılın sonlarından itibaren 'coğrafi epidemiyoloji' ve 'hastalık ekolojisi' olarak iki ana eksende şekillenmiştir. Bu araştırmalarda salgın hastalıkların dağılış kalıplarının ve buna bağlı olarak meslek veya beslenme gibi ortaya çıkış nedenlerinin belirlenmesi (Hamlin, 1998: 192) amacıyla bu hastalıkların haritalandırılması yapılmıştır. Örneğin 1788 'de sarıhummanın dağılışını gösteren haritaların hazırlanması, yine 1820'lerde koleranın Hindistan'dan Avrupa ve Asya ile Kuzey Amerika'ya hızla yayılması nedeniyle bu hastalığın görüldüğü tarihleri gösteren haritaların yapılması başarılı çalışmalar olarak kabul edilmektedir. Tıbbi haritaların en iyi bilenlerinden biri de 1844-1854 yılları arasında Londra'nın Soho bölgesindeki Golden Square'de görülen kolera salgını ile ilgili olanıdır. Bu salgında John Snow, sudan bulaşan bir hastalık olan koleradan ölenler ile bu yerde bulunan bir su pompasından su içenler arasındaki ilişkiyi göstermek için bir harita hazırlamış ve ölümlerin bu su pompası etrafinda yoğunlaştığı gerçeğini ortaya koymuştur (Timor, 1996: 303-305; McLean, 2006: 2). Böylece istatistikler; nüfusun kontrolü, hastalıkların engellenmesi ve halk sağlığ1 politikalarının geliştirilmesinde bilgi ve iktidar arasındaki ilişkinin teknik aracı rolü görmüştür.

Turkish Studies, 15(4) 
Diğer yandan 'hijyen fikri', toplumsal bedenin devlet tarafindan idare edilmesi gereken bir şey olduğu fikrini pekiştirmeye yardım etmesi açısından çarpıcıdır. Avrupa'da 19.yüzyıl hıfzıssıhha reform hareketlerini, düzensiz bir devletin nüfus üzerinde yeniden düzenleyici gücüne inancı temsil eden siyasi imgelemin bir parçası olarak ele alan Mark Neocleous (2014: 57-59) düşüncesini 'arınma' metaforu ile ilişkilendirmiştir. Ahlaki ve fiziksel arınmanın hijyen metaforu ile pekiştirilmesi ise devletin gözetim ve denetim mekanizmaları ile sağlanmıştır. Başka bir deyişle, kapitalist gelişmenin yarattığı sorunlara karşı sağlık hizmetleri, toplumsal düzenin inşasında ve kontrolünde vazgeçilmez role sahip olmuş ve tarihsel olarak merkezileşme süreçlerini desteklemiştir. Devlet müdahalesindeki bu rasyonalite, Fransa'da Louis Pasteur (1871) ve Almanya'da Robert Koch'un (1884) çalışmaları sayesinde hastalıkların mikroplarla bulaştığının kanıtlanması ile ivme kazanmıştır (Gascoigne, 2019: 105) Porter'ın da ileri sürdüğg̈ gibi (1999: 108), bakteriyoloji ve mikrobiyoloji ile enfeksiyonları önlemek için çeşitli yollar arayışı, yeni bir paradigma değişimine yol açarak halk sağlığında yeni bir tür merkezileşmeyi kolaylaştırmıştır.

\section{Kameralizm ve Polis Biliminde Nüfusun Sağlığı}

Otuz Y11 Savaşları (1618-1648) sonrası Orta Avrupa'da özellikle de Almanca konuşulan topraklarda küçük devletciklerin ortaya çıkması nedeniyle, merkezi yönetimin gücünün arttırılması ve rejimin sürekliliğinin sağlanmasına duyulan ihtiyaç, kameral bilimlerin doğmasına neden olmuştur (Aktel vd., 2015: 83-84). 17. ve 18. yüzyılda Alman devletlerinde mutlak monarşinin yönetim ve ekonomi politikasındaki merkezileşme eğilimlerini ve pratiklerini açıklayan, savunan ve yönlendiren düşünceleri ifade eden kameralizm (Rosen, 1953: 24), kamunun refahı ve sağlığ 1 için her türlü önlemi alabilen, bireylerin hak ve özgürlüklerine müdahale edebilen ve bu yolla toplumsal düzeni sağlamayı amaçlayan bir devlet biçimini ifade eden 'polis bilimi'ne içkindir. Kameralistler, daha fazla ekonomik büyümeye yol açacak ulusal refah için bir temel oluşturmak amaciyla polis işlevini sistematik şekilde kullanmışlardır (Backhaus, 2009: 175). Kameralistler, iyi düzenlenmiş polis devletinin sadece gelir toplamak için meşruluk kaynağına sahip olmakla kalmayacağını, aynı zamanda devlet iktidarının toplumsal hayata nüfuz etme kabiliyetini geliştireceğine inanmaktaydılar (Wakefield, 2009: 9). 'Modern yönetim sanatı' veya 'devlet rasyonalitesi' olarak ortaya çıkan polis biliminde (Carroll, 2002: 472) beşeri sermaye ve onun gelişimi, ekonomik kalkınmanın temelini oluşturmaktaydı. Doğrudan devlet müdahalesi ile nüfusun üretken kapasitesini artırma arayışının bir sonucu olarak da (Weisz, 1986: 422) sağlık, devletin sermaye yapısının bir bileşeni konumundaydı. Kameralistler tarafindan doğal hukuk teorilerini temel alan sağlık söylemi, nüfus artışını sağlamayı hedefleyen bir politikayı teşvik etmiştir. Bu düşüncenin gerisinde Otuz Yıl Savaşlarının yarattığı yıkım olduğu ileri sürülebilir. Çünkü savaş koşullarının salgın hastalıkların yayılması için yarattığı uygun ortam nedeniyle tifüs ve 1830'lu yılların başlarında ortaya çıan veba, Kuzeydoğu ve Güneybatı Almanya'da çok yüksek ölüm oranlarına sebep olmuştu. Nitekim modern tarihçiler, Otuz Yıl Savaşlarının bir bütün olarak Alman devletlerinde nüfusun \% 15-20'sinin kaybı ile sonuçlandığını düşünmektedirler (Hays, 2005: 97-99).

İnsanların refahının, zenginlik ve sağlıklarına bağlı olduğunun farkında olan kameralistler; nüfusun sağlığı ve düzenlenmesi, okulların ve üniversitelerin kurulması, insanların çalışmalarının teşvik edilmesi, yoksulların bakımı ve güvenliğin sağlanması ile ülkenin güzelliğinin korunması gibi konuları devletin sorumluluğu olarak kabul etmekteydiler (Rosen, 1953: 32). Nüfusun sağlığı ise neredeyse bütün kameralistler tarafindan devletin merkezileşmesinin temel dayanağı olarak görülmüştür. Erken dönem kameralistlerden sayılan Melchior von Osse, sağllğı güçlü bir toplumun en önemli bileşeni olarak nitelerken, salgınlar ve vebayı bir devletin parçalanmasına ve düzeninin bozulmasına yol açan unsurlar arasında saymıştır (Small, 2001: 42). Kameralizmin Adam Smith'i olarak adlandırılan Ludving von Seckendorf’a (1673-1763) göre, devletin görevi refahı arttırmak ve sağlı̆̆ korumaktır. Ona göre bunun için devlet; bir hükümet programı ile ebelerin korunması ve gözetimi, yetimlerinin bakımı, doktor ve cerrahların atanması, veba ve diğer bulaşıcı hastalıklara karşı koruma, ruhsal şiddetlerin ve tütünün aşırı kullanımı, gıda ve su muayenesi, kasabaların 
temizlenmesi ve kanalizasyon önlemleri, hastanelerin bakımı, yoksullara sağlık hizmeti ile ilgilenmelidir (Rosen, 1953: 25-28). Benzer şekilde, toplumsal bedeni kontrol etmenin yolunun tıp bilimi ve hijyen yoluyla bedeni kontrol etmekten geçtiğini belirten Leibniz'e (1646-1716) göre de doktorlar ve hijyen ağı, günlük yaşamın kontrol ve koordinasyonunda yöneticiler kadar önemli bir role sahipti (Sechel, 2003: 161). Bu yüzden de doğum, ölüm oranları ile ölüm nedenlerinin sürekli analiz edilmesi gerektiğini ileri sürmüş ve bunun için bir kurul kurulmasını önermiştir. Leibniz'in halk sağlığını kontrol etmek için tıbbi bir otorite önerisiyle bağlantılı mıdır bilinmez 1685 yılında Prusya'da, bir Hıfzıssıhha Kurulu (Collegium sanitatis) kurulmuştur (Rosen, 1953: 29). Leibniz'in bir takipçisi olan Christian Wolff ise 1721 yılında yazdığı kitapta, 'devletin refahı' ile 'insanların sağlı̆̆ı' arasında yakın bir ilişki olduğuna işaret ederek zengin ve nüfusu fazla devletlerin güçlü olduklarını göstermiştir. Eğer nüfusun arttırılması isteniyorsa da ortalama insan ömrünün uzaması gerektiğini, bunun için bulaşıcı hastalıkları önleyecek iyi hijyen düzenlemelerinin de en az zenginlik kadar önemli olduğunu belirtmiştir (Rosen, 1953: 30). Bu görevin de devlete ait olduğunu belirten Wolff, bir monarkın tıpkı bir babanın çocuklarına hizmet ettiği gibi nüfusa hizmet etmesi gerektiği tavsiye etmiştir (Sechel, 2003: 162).

\section{Salgınlar ve 'Medikal Polis' Fikrinin Ortaya Çıkışı}

Kameralistler tarafindan bir kamu politikası sorunu olarak sağlı̆̆ın gündeme getirilmesi, 'medikal polis' kavramının yaratılmasına, yani merkezi yönetim tarafindan bir tıbbi politika oluşturulması ve idari düzenlemeyle uygulanması düşüncesi hızla popülerlik kazanmıştır. 17. ve 18. yüzyıllarda hükümdarın güvenliğini sağlamak, devletin gücünü ve refahını arttırmak için sağlık alanının ön plana çıkardığı medikal polis kavramı; mutlak, merkantilist Alman devletinin politik ve toplumsal temelinden kaynaklanan teorilere, politikalara ve uygulamalara son derece uygun bir kavramdır. Bir salgın tıbbının, ancak bir polis tarafindan desteklenirse var olabileceğine inanan Foucault (1973: 25-26) da sağlık ve hijyen sorunlarının tıp alanı ile ilgili olduğu kadar 'polis' alanı ile de ilgili olduğunu ileri sürmüştür. Devlet iktidarının toplumsal hayata nüfuz etme kabiliyetinin geliştirilmesinde polisliğin merkezi rolü nedeniyle, medikal polisin bir biçimi olarak hıfzıssıhha reformları yoluyla düzen arayışına önem verilmiştir. Bu çerçevede siyaset filozoflarının öğretileri ve polis bilimi kuramcılarının etkilediği doktorlar, polis kavramını benimseyerek tıp ve sağlık sorunlarına uygulamaya başlamışlardır.

'Medikal polis' terimi ilk kez 1764 yılında Wolfgang Thomas Rau tarafından nüfusun idari düzenlemesi yoluyla bir devlet sağlık politikasının oluşturulması ve uygulanmasını tanımlamak için kullanılmıştır (Neocleous, 2000: 88). Argümanlarını Wolffun politik teorisine dayandıran Rau, her hükümdarın barış ve savaştaki yükümlülüklerini yerine getirebilecek sağlılı insanlara ihtiyacı olduğuna dikkat çekmiştir. Bu nedenle devlet, insanların sağlığını korumalıdır. Tıp mesleği sadece hastaları tedavi etmekle kalmaz, aynı zamanda nüfusun sağlığını da denetlemekle yükümlüdür. Bunun için Rau; tıp eğitimini düzenleyecek, eczaneleri ve hastaneleri denetleyecek, salgın hastalıkları önleyecek, yetkisiz kişilerce tıbbi suiistimalleri engelleyecek ve halk sağlığ eğitimini içeren 'medikal polis' düzenlemeleri (yasa, yönetmelik) çıkarılmasını önermiştir (Rosen, 1953: 39). 1771 yılında Christian Rickmann, 1773'te J.F. Zückect ve 1784 yılında J. P. Brinkman yazdıkları eserlerde devletin güvenliğini artırmak için, hükümetin sefaleti, hastalığı ve ölümü önlemeye gayret etmesi gerektiğine, bulaşıcı ve salgın hastalıkların yayılmasını önlemek için bir medikal polis örgütlenmesine gereksinim olduğunu sıklıkla dile getirmişlerdir (Rosen, 1953: 39-41).

Ancak kavram, Viyana'daki genel bir hastanenin yöneticisi ve Hapsburg mahkemesinin doktoru olan Johann Peter Frank'in (1745-1821) System of an Encompassing Medical Police adl1 ilk cildi 1779 'da, altıncı ve son cildi 1817 'de yayınlanan kitabı ile popüler hale gelmiştir. Hatta Frank' 1 n bu eseri medikal polis fikrinin Almanya'nın ötesine yayılarak Avusturya ve Rusya'daki tıbbi uygulamaların gelişimini etkilemiştir (Backhaus, 2009: 184). Bu kitapta Frank; evlilik, hamilelik ve kişisel hijyen gibi hastalık yayabilecek kişisel davranışlar yanında kanalizasyon, saf su temini, sokak 
temizliği, fuhuş ve aşırı kalabalık kontrolü gibi toplumsal hijyen önlemleri ile devletin bulaşıcı ve salgın hastalıkları önleyebileceğini göstermeye çalışmıştır. Medikal polisi, genel olarak polis bilimi bağlamına yerleştiren Frank, polis biliminin en önemli konusunun toplumda yaşayan insanlara belirli esaslara dayalı olarak sağlık hizmet sunmak olduğunu savunmuştur. Hatta ona göre, devlet "beşikten mezara" halkın sağlığı ile ilgilenmeliydi. Nitekim 18. yüzyılın başlarında medikal polis kavramı, yavaş yavaş kurumsal biçimlerde kristalleştirmeye başlamıştır.

Medikal polis kavramının yerleşmesinde 18. yüzyıl kameralizminin önde gelen temsilcilerinden biri olan Johannes Heinrich Gottlob von Justi önemli bir yere sahiptir. Justi'nin görüşüne göre, devletin iç idaresi güç ilişkilerinin ağırlık merkeziydi. Diğer kameralistler gibi, devletin mevcut kaynakları koruyup geliştirmek ve toplumsal refahı arttırma yükümlülügüune dikkat çekmiştir. Bu amaçla polis bilimi de uygun bir kurumsal örgütlenme yoluyla toplumun refahının ve sağlığının korunması ve geliştirmesi ile uğraşmalıdır. Justi, 1760 yılında 'Devletlerin Güç ve Mutluluğınun Temel Dayanakları' adlı eserinde, nüfusun mutluluğunu maksimum yapmanın yolunun nüfusu arttırmak ve yaşam süresinin uzatmaktan geçtiğini dile getirmektedir. Hatta bu amacı gerçekleştirmek için kalıtsal hastalıkları olan veya üreyemeyen kişilerin evlenmelerine izin verilmemesi, doğurganlığ1 azalttığ1 ve evliliği caydırdığ 1 için fuhuşun önlenmesi ve alkol bağımlılığının tedavi edilmesi gibi tedbirlerin alınmasını bile önermiştir (Rosen, 1953: 33). Ancak bulaşıcı ve salgın hastalıkların bu süreci sekteye uğrattığından şikâyet eden Justi sağlıklı bir çevrenin yaratılmasının önemine dikkat çekmiştir. Veba ve diğer bulaşıcı hastalıkları, ülke sınırlarında izolasyon ve karantina tedbirleri ile kontrol etmeyi öneren Justi, bu hastalıkların yıkıcı etkileri nedeniyle de devlet müdahalesinin kaçınılmaz olduğunu öne sürmüştür (Backhaus, 2009: 181). Salgın hastalıklarla mücadelede Justi'nin günümüzde de geçerliliğini koruyan önerileri şöyle özetlenebilir (Backhaus, 182):

i. Salgın hastalık oluşan ülkelerle insan ve mal giriş-çıkışına kısıtlama getirilerek, sınır güvenliği korunmalıdır.

ii. Birinin bir hastalıkla temas edip etmediğinden şüpheleniliyorsa, bu kişi 40 gün boyunca izole bir yerde karantinaya alınmalıdır.

iii. Eğer bir şehir veya daha büyük bir bölgeye bulaş olmuşsa askerlere tüm alanı izole etmeleri emredilmelidir.

iv. Salgın hastalıklarla ilgili verileri ve ölüm nedenlerini incelemek, hekim ve sağllk hizmet kalitesini değerlendirmek üzere doktorlar ve bürokratlardan oluşan biri 'Sağlık Kurulu' (Health Board) diğeri "Tıbbi Kurul” (Medical Board) olmak üzere iki kurul oluşturulmalıdır.

Justi, siyaset sanat1 ve polis bilimi arasında bir ayrım yaparak, siyasetin görevinin devletin iç ve dış güvenliğini sağlamak, polis biliminin görevinin ise farklı bileşenlerden oluşan devletin refahını korumak ve arttırmak olduğunu vurgulamıştır (Sechel, 2003: 162). Nüfusun sağlığı devletin refahının bir bileşenidir. Nüfusun büyümesi ve gelişmesi devletin refahını arttırmaktadır (Rosen, 1953: 33-34). Nüfusun sağlığı ile ilgili düşüncelerini Wolff'un polis bilimi üzerine fikirleri üzerine inşa eden Justi, insanları ulusların zenginliği olarak gördüğünden sağlığı bir tüketim değil yatırım meselesi olarak ele almıştır. Kameralistlerin bu görüşü, modern sağlık ekonomistlerinin sağlığı beşeri sermayenin bir bileşeni olarak gören anlayışı ile benzeşmektedir. Belki de bu yüzden olsa gerek Backhaus (2009: 177-184), Justi’yi Avrupa kıtasında halk sağlığı geleneğinin kurucusu olarak nitelerken modern devletin sağlık politikalarının kökeninin burada bulunabileceğini ileri sürmüştür. Koruyucu sağlı hizmetlerinin ve bu amaçla yapılan harcamaların ekonomik büyümeye ve dolayısıyla devletin refahına katkıda bulunan bir yatırım olduğu görüşü günümüzde hala geçerliliğini korumaktadır.

Joseph von Sonnenfels de 1765-76 yılları arasında yayımlanan 'Polis Biliminin Ilkeleri' adlı üç ciltlik eserinde medikal polis uygulamaları altında devletin refahını ve halkın sağlığını etkileyen şiddet suçları, yoksullara yardım, hasta bakımı, salgın hastalıkların önlenmesi, tıbbi ve cerrahi 
uygulamaların düzenlenmesi, temiz gıdaların güvence altına alınması, şehirlerin temizliği, kürtaj gibi konuları ele almıştır (Carroll, 2002: 472; Rosen, 1953: 35). İnsanoğlunun doğal durumunu aksaklığa uğratan hastalıklardan nüfusu koruyacak her türlü tedbirin alınmasını öneren Sonnenfels, tıp fakülteleri, akıl hastaneleri ve karantina merkezlerinin önemine dikkat çekmiştir (Sechel, 2003: 163).

Kameralizmin ve dolaylı olarak medikal polis fikrinin Avrupa'da etkilediği yerlerin başında ise Habsburg Monarşisi olarak adlandırılan ve 1526-1806 yılları arasında Habsburg Hanedanlığ tarafından yönetilen Orta Avrupa (özellikle Avusturya, Macaristan, Bohemya) toprakları gelmektedir. 18. yüzyılın başlarında İmparatoriçe Maria Theresa ve oğlu II. Joseph döneminde sayısız savaştan ve ekonomik krizden ciddi şekilde etkilenen Monarşiyi merkezileştirme ve modernleştirme çabası bir dizi reformu da beraberinde getirmiştir. Kameralist anlayışın yoğun etkisinin görüldüğü bu dönemde Habsburg'tan Transilvanya'ya kadar geniş bir coğrafi alanda etkili olan salgınlar (veba, kolera, çiçek hastalığı) halk sağlığı alanında reformların uygulanmasını teşvik etmiştir (Sechel, 2003: 160-161). Bu yüzyılda Leibniz, Wolff, von Justi ve Sonnenfels gibi Alman ve Avusturyalı kameralist düşünürlerin toplumsal bedeni kontrol etmek için tıp bilimi ve hijyen yoluyla bedeni kontrol etme fikri ve ideali, Habsburg topraklarındaki hakim düşünce olmuştur. $\mathrm{Bu}$ doğrultuda hıfzıssıhha reformları sadece salgın gibi pragmatik bir nedene dayanmayıp, aynı zamanda dönemin genel düşünce yapısının ve ideallerinin bir dışavurumudur. Nüfus artışını sağlama politikası, salgın hastalıklarla savaş ve bir halk sağlığı programının oluşturulmasının arkasındaki temel düşünce, sağlıklı, mutlu ve zengin nüfusun devletin refahını temsil ettiği gerçeğiydi. $\mathrm{Bu}$ doğrultuda salgın durumunda mortalite ve morbiditeyi azaltarak, nüfusun yaşam kalitesini yükseltmeyi amaçlayan önlemler sürekli olarak uygulanmıştır. Özellikle dış ülkelerden gelebilecek salgın tehditlerine karşı Avusturya sınır bölgelerinde hijyen koridorları ve hıfzıssıhha kurulları oluşturuldu ve karantina istasyonları inşa edildi. Devletin, gelirlerini arttırmak için kamusal ve özel hayata sistematik bir müdahalesini ortaya koyan bu politika, bir yandan Monarşinin otoritesini ve prestijini güçlendirirken, diğer yandan da salgınları önemli ölçüde azaltarak güvenlik ve düzenin sağlanmasını desteklemiştir (Sarıyıldız, 1994: 330; Sechel, 2003: 168-169). Bu bağlamda, Kıta Avrupasında medikal polis düşüncesinin; siyasi, ekonomik ve toplumsal olarak devletin merkezileşmesine hizmet eden Kameralizmin temel bileşenlerinden biri olduğu ileri sürülebilir.

\section{Halk Sağlığı ve Merkezileşme: Viktoryan Dönemi İngiliz Devleti}

Birçok Avrupa ülkesinde hem sivil hem de denizcilik alanında geliştirilen karantina uygulamalarına paralel olarak, 16. yüzyılda İngiltere'de Tudor hanedanlığı döneminde de yönetsel düzenlemelerle vebaya karşı güçlü tedbirler alınmıştı. Avrupa ülkeleri arasında İngiltere, çöp toplama ve sokak düzenlemelerinde de öncü rol oynamıştı. İngiltere'de halk sağlı̆̆ sorununun bir kamu politikası haline gelmesi, 18. yüzyılın sonlarından itibaren endüstriyel bir topluma geçişte devletin değişen rolü ile ilişkilidir. $1815^{\prime}$ ten sonra, savaşların yarattığı ağır askeri harcama yükünden kurtulan kamu maliyesi, giderek artan bir şekilde iç sosyal politikaya odaklanmaya başlamış ve halk sağlığı politikası da bu gelişmelerden etkilenmiştir. İngiltere'de artan sanayileşme, nüfusun demografik yapısını ve coğrafi dağılımını değiştirerek kentleşmeyi hızlandırmıştır (Porter, 1999: 110). Sanayileşme ile kentlerin aşırı büyümesi sonucu sağlığa yönelik çevresel tehditler katlanarak artmıştır. Başta Londra olmak üzere İngiltere'nin birçok bölgesinde yaşanan aşırı kentleşme; konut arzının yetersizliğine, endüstriyel atıkların artmasına ve çevre kirliliği, içme suyu, kanalizasyon ve çöplüklerin yetersiz kalmasına yol açmış ve bunun sonucu olarak ortaya çıkan yoksullaşma nedeniyle bebek ölümleri ve salgın hastalıklar yaygınlaşmaya başlamıştır. Viktoryan döneminde 1831-1832, 1848-1849, 1853-1854 ve 1866 yıllarında olmak üzere dört kolera salgını yaşanmış ve toplumda büyük bir bunalıma neden olmuştur. 19. yüzyılda sadece kolera değil çiçek hastalığı, tifüs, tüberküloz ve difteri gibi hastalıklar da yaygın olarak görülmüştür. Örneğin İngiltere'de sadece 1838'de 59 bin kişi tüberkülozdan ölürken, 1837-1840 arasında 42 bin kişi çiçek hastalığından ölmüştür (McLean, 2006: 3-4). Ancak kolera salgınları, halk sağlığı alanındaki gelişmeleri tetikleyici etken olmuştur. Bununla birlikte, Viktoryan döneminde aristokrasi hızla kapitalistleşmenin yaratığı bu koşulların 
sadece hastalık üretmediğine, aynı zamanda yoksullar arasında ailelerin kutsallığını yok ettiğine, insanları suç, sarhoşluk, zina gibi ahlaksızlıklara yönelttiğine inanıyordu. İnsanları sosyalizme veya ateizme teşvik eden bu politik tehlike ile birlikte, sanayileşme ve kentleşmenin ortaya çıkardığı sınıfsal ayrım da toplumsal istikrarı tehdit ettiğinden, toplumsal kesimlerin beklentilerine uygun bir sağlık reformu zorunluluğu ortaya çıkmıştı. Aslında bu durum, kapitalizmin gelişmesine koşut olarak İngiltere'de kendiliğinden ortaya çıkan siyasal merkezileşme sürecinin bir yansımasıydı. Bu açıdan sağlık reformu, İngiltere'de Monarşi ve aristokrasinin, devlet gücünü birlikte kullanarak ortak denetime dayalı bir merkezileşmeyi gerçekleştirme girişiminin bir ürünü (Akbulut, 2007: 263-267) olarak değerlendirilebilir. Siyasal ve toplumsal dönüşümü de içinde barındıran sağlık/hijyen reformu tartışmalarının odağındaki kişi ise Edwin Chadwick olmuştur. Jeremy Bentham'ın öğrencisi olan Chadwick ilk olarak 1837-1838'de Doğu Londra'daki tifüs salgınını incelemiș ve bölgedeki hijyen koşulları üzerine bir rapor hazırlamıştır. 1842 y1lında 'Büyük Britanya Çalı̧̧an Nüfusunun Sihhi Koşulları' üzerine hazırladığı rapor ise İngiltere'de halk sağlığı tarihinde bir dönem noktasıydı. Chadwick bu raporda kanalizasyon, sokak ve kaldırım, içme suyu, konutların ve ticaretin ortaya çıkardığı sorunların hijyen düzenlemesini sağlamak üzere yerel kurulları yönlendirmek için merkezi bir halk sağlığı otoritesinin kurulmasını, hijyen düşüncesinin bir sağlı mühendisliği yaklaşımı ile her alana uygulanmasını önermiştir. Hijyen düzenlemeleri; altyapı ve inşaat sektöründen büyük mühendislik projelerine kadar birçok alanı etkilemiştir (Porter, 1999: 117; McLean, 2006: 7). Chadwick'in nüfusun sıhhi koşullarına odaklanma fikrinin Alman medikal polis uygulamaları ile bağlantılı olduğunu ileri süren Rosen'ın (1953: 23) bu savını doğrular şekilde, 1847'de Prusya hükümetinin teklifi ile İngiltere'nin kırsal bir bölgesinde etkili olan bir tifüs salgınını araştırmak üzere Rudolf Virchow görevlendirilmiştir. Virchow analizi sonucunda salgın sorununa en rasyonel yaklaşımın, salgını ortaya çıkaran koşulların değiştirilmesi olduğu savunarak (Waitzkin, 1978: 264), adeta sağlıksızlığın toplumsal etmenlerde aranması gerektiğine vurgu yapmıştır.

1842 tarihli raporun ve kısmen gelişen politik hareketlerin etkisiyle ilk İngiliz Halk Sağlı̆̆ Yasas1 1848'de kabul edilmiştir (McNeill, 1976: 240; Erdem, 2002: 10). Ulusal merkezi bir sağlık bürokrasisi yaratma potansiyeli mevcut olmasına rağmen, yasanın uygulanması büyük ölçüde yerel otoritelerin takdirine, isteğine bırakılmıştı. Bu çerçevede 1848-1853 yılları arasında Halk Sağlı̆g Yasası'nı kabul etmek için 284 şehir başvurmuş ve 103 şehirde uygulanmıştır (Porter, 1999: 118119). Yasa, Genel Sağlık Kurulu (General Board of Health) adlı merkezi bir otorite yarattı ancak pratikte ömrü kısa sürdü. Chadwick'in Genel Sağlık Kurulu ile daha fazla merkezileşmeye yönelmesi üzerine The Times editörleri, merkezi yönetimin kolera ile riske girmekten ziyade baskıcı sağlık tedbirlerini tercih ettiğini açıklamışlardır (Carroll, 2002: 490-491). Diğer yandan da yerel bir sağlık kurulu olarak altyapı ve çevre düzenlemelerini denetlemekle görevli yerel belediye meclisleri, sıhhi bir otorite haline gelmiştir.

Liberal bireyciliğin yaygın söylemine, bırakınız yapsınların (laissez-faire) ekonomik ideolojisinin desteklenmesine ve muhtaçlara sosyal hizmet sunma konusundaki gönüllü çabaya güvenilmesine rağmen, İngiltere'de Viktorya devleti genişlemeye ve giderek müdahaleci olmaya devam etti (Porter, 1999: 111). Merkezi yönetim tarafından başlatılan küçük ve geçici adımlar, 18. ve 19. yüzyılda salgın hastalıkların yayılmasını engellemek için yavaş yavaş yaygınlaşan ve ulusa dayatılan polis müdahaleleri şekline dönüştü. Avrupa kıtasında monarşik merkezi yönetim biçiminin bir formu olarak görülen 'medikal polis' düşüncesi ile İngiltere'de 'halk sağlığı'nın gelişimi arasındaki örüntüye dikkat çeken Carroll (2002: 463-464) söylem değişiminin kültürel ve politik etkenlerden kaynaklandığını ileri sürmüştür. Bu bağlamda Cristopher Hamlin'in belirttiği gibi (1998: 191-193) İngiltere'de polis fikrinin merkezileşmesi, güçlü yerel yönetim geleneği tarafından sınırlandırılmıştır. Halk sağlığının korunmasında polisin rolü, bireysel özgürlük ve sosyal adalet mücadelelerine bağlanmıştır. Ancak bu ulusal farklılıklar bağlamında bile, İngiltere'de polisin gelişimi Avrupa ülkelerine benzer şekilde ilerlemiştir. İngiltere'de genel olarak halk sağlığı tarihi içinde medikal polis unsurlarını somutlaştıran düşünce ve pratikler bulunmakta olup; bu pratikler 
özel, ailevi ve ticari konularda denetim ve gözetim, bilgi ve istihbarat toplama ve doğrudan müdahale uygulamalarında ortaya çıkmıştır (Carroll, 2002: 465).

$\mathrm{Bu}$ dönemin siyasi ve ekonomik felsefedeki çelişkili gerilimlere rağmen, halk sağlı̆̆ politikası liberal demokratik devlet içinde bir bürokratik büyümeye örnek teşkil etmiştir. İngiliz devleti, müdahaleci bir bürokratik sağlı yönetimi sisteminin oluşturulması yoluyla ekonomik genişlemenin salgın maliyetlerine çözüm aramıştır. Başlangıçta devletin rolü, yerel otoritelerin içinde bulundukları koşulları korumak için müdahale etmelerini sağlamaktı. Ancak halk sağlığı kurallarının dili, giderek baskı ve zorunluluk getiren bir anlayış ortaya çıkardı. Devlet müdahalesinin planlayıcıları; salgın hastalığın neden olduğu erken ölümleri engelleyerek, yoksulluğun büyük bir kısmının - ve bireyler, endüstri ve toplum üzerindeki maliyetlerinin - azaltılabileceğini varsayarak bunu haklı çıkardı. İngiltere'de halk sağlığına müdahale girişimi merkezi hükümetin eylemleri tarafindan yönlendirildi, ancak pratik uygulaması için yerel yönetimlere güvendi (Porter, 1999: 111). $\mathrm{Bu}$ bağlamda, halk sağlığı hizmetinin bir dereceye kadar yerel yönetim takdirine açık olması ve halkın yerel demokratik süreçlere katılımının sağlanabilir olması devam etmiştir. Ancak, İngiltere'deki halk sağlığı müdahalesinin karşıtları, bunu yerel yönetim özerkliği için bir tehdit ve merkezi devletin, onların işlerine kabul edilemez bir müdahalesi olarak algılamıştır. Halk sağlığı müdahalesi, erken Viktoryan dönemde bir yandan merkezi yönetimin otoriteryen, paternalist gücünün kötü şöhretli büyümesi (Lawes, 2000: 4-5) ve diğer yandan belirli bir mesleğin - tıp mesleğinin - despotik etkisinin büyümesi olarak nitelendirilmiştir. Bu suçlamalar, devletin müdahaleleri, örneğin zorunlu çiçek hastalığı aşısı alanında, daha kapsamlı ve zorunlu hale geldikçe güç kazandı. Viktorya yönetimi tarafından devlet iktidarını güçlendirmenin bir yolu olarak halk sağllğına bürokratik müdahalenin büyümesinin tercih edildiği söylenebilir. İngiltere'de bir halk sağlığı sisteminin oluşturulması, piyasa ilişkilerinin serbest işleyişini güçlendirmek için yasal düzenlemeleri kullanmayı amaçlayan politik bir ekonomik felsefe üzerine kurulmuştur (Porter, 1999: 120). Çalışanların erken ölüm oranını engelleyerek yoksulluk ve yoksunluk maliyetini azaltmak, yeni bir hükümet teorisinin; verimlilik ve adaletin ancak devlet işlerinin bilimsel ve rasyonel örgütlenmesi yoluyla elde edilebileceğini iddia eden bir özelliğiydi.

Hijyen fikrinden, medikal yönetime geçiş ise 1854 yılında Chadwick'in yerine bir doktor olan John Simon'un getirilmesiyle gerçekleşti. Merkezi yönetimin sağlık politikalarını yönlendirmek ve yerel yönetim uygulamalarına egemen olmak için Simon, devletin halk sağlığının bütün alanlarını sistematik ve kapsamlı bir şekilde ele almasını içeren 'devlet tıbbı' kavramını ön plana çıkarmıştır. Hastalık nedenleri ve türleri ile ilgili yıllıklar ile 1858 ve 1866 yıllarında çıkarılan halk sağlığ yasalarıyla yerel yönetimlere daha fazla yetki ve sorumluluk yüklenmesi bu dönemin dikkat çeken gelişmeleridir. Simon'un 1876 'da istifası üzerine devlet tıbbının merkezi yönetim üzerindeki etkisi de azalmasına rağmen, İngiltere'de nüfus sağlı̆̆ üzerinde merkezi devlet kontrolünü artmaya devam etmiştir. Viktorya İngiltere'sinde nüfus sağlığını düzenleyen bir devlet aygıtının büyümesi, liberal demokrasinin bürokratik yönetime olan ihtiyacını göstermiştir. Sanayileşme ve salgın hastalıklarla ilgili kıta çapında endişeler, İngiltere bağlamında politik ekonominin faydacı felsefesi tarafindan meşrulaştırılan devletin müdahaleci çözümü ile teşvik edilmiştir (Porter, 1999: 145). Devlet müdahalesi, yerel yönetimleri başlangıçta teşvik etme, daha sonra uygulamaya mecbur bırakma şeklinde gerçekleşmiştir. Halk sağlığı politikalarını uygulayan yerel yönetim otoritelerinin sayısının artması, nitelikli ve eğitimli halk sağlığı görevlileri yetişmesini sağlamıştır. Bununla birlikte, İngiltere'de sağlık üzerinden toplumsal ilişkilere kolektivist müdahale, sivil özgürlüğün ideolojik hedefleri ile toplum yararı arasındaki gerilimi artırmıştır. Demokratik ve bürokratik politikalar arasındaki gerilim, sadece İngiltere'de değil, gelişmiş ve gelişmekte olan tüm ülkelerde, modern sağlık politikalarının oluşturulmasında merkezi bir ikilem olmaya devam etmektedir. 


\section{ABD'de Karantina Uygulamaları ve Federalizm Tartışmaları}

ABD'de halk sağlığının gelişim biçimi, İngiltere ile aynı özelikleri göstermemiştir. ABD'de halk sağlığı alanında reform çabaları, uzman profesyoneller eliyle değil, yerel gönüllü girişimlerle etkin bir şekilde yürütülmüş ve özellikle de 'temizlik imandan gelir' anlayışı ile bağlantılı Püriten ahlak kurallarıyla desteklenmiştir. Çünkü merkezi yönetim anlayışının Amerikan toplumunun temel değerlerinden olan bireysel hakların mutlak egemenliğine zarar vereceği endişesi, toplumda bu tür girişimlerin tepkiyle karşılanmasına neden olmaktaydı. Bu düşüncede kırılmayı ise artmaya başlayan salgın hastalıklar oluşturmuştur. 18. yüzyılın sonlarında sıtma, sarıhumma gibi salgınlar, karantina kurallarını uygulamak için merkezi yönetimi harekete geçirmiş ve 1798 yılında yaralı ve hasta denizciler ile ticari gemilerin mürettebatına hizmet vermek üzere Deniz Hastanesi İdaresi (Marine Hospital Service) kurulmuştur. Daha sonra New York, Boston, Washington, New Orleans gibi birçok büyük eyalette salgın hastalıklara karşı karantina tedbirlerini yürütmek üzere geçici sağlık kurulları oluşturulmuştur. Ancak 1861-1865 Amerikan İç Savaşı'na kadar ABD'de halk sağlı̆̆ı alanında önemli bir gelişme kaydedilmemiştir.

Amerikan federalizminde merkezileşme eğiliminin bir ürünü olan Amerikan İç Savaşı, kuzey ve güney bölgeleri arasındaki ulusal ve uluslararası sermayeye eklemlenme süreci olarak değerlendirilebilir. Bu yönüyle Amerikan İç Savaşı aracılı̆̆ıyla, kapitalizmin gereksinim duyduğu ekonomik bütünselliğin inşası sağlanmaya çalışılmıştır (Akbulut, 2007: 319; Önen ve Reyhan, 2011: 54). Amerikan merkezileşmesinde önemli bir yer tutan Amerikan İç Savaşı'nda 600 bin askerin büyük bölümünün dizanteri ve tifo nedeniyle ölmesi, Amerikan Ordusunda hıfzıssıhha komisyonları kurulmasını, hijyen ve izolasyon tedbirlerinin alınmasını zorunlu kılmıştır (Porter, 1999: 149). Amerikan Ordusunda bu hifzıssihha reform pratikleri, eyaletlerde yeni hijyen programlarının uygulanmasını tetiklemiştir. Bir nevi sağlığın ulusal boyutu, merkezileşmenin ve planlamanın meşruluğuna temel oluşturmuştur. 1870'lerden sonra eyaletlerde bulaşıcı hastalıkların önlenmesi için hıfzıssıhha reformları uygulanmaya, gida denetimleri yapılmaya başlandı ve bunun için laboratuvarlar kuruldu. Deniz Hastanesi İdaresi'ne 1880 sonrası kolera ve sarıhumma gibi salgin hastalıkların kontrolü için karantina yetkileri verilmiştir. Bununla birlikte sanayileşme, kentleşme ve göçün hızı arttıkça federal yönetim tarafindan sağlık alanında bütüncül eylemlerin uygulanması ihtiyacı ortaya çıktı. Özellikle göçmen kent nüfusu arasında bulaşıcı hastalıkların ve ölümlerin artması, salgın hastalıkların sağlıklı bir toplumsal düzene tehdit oluşturduğu algısını yerleştirdi. Salgın hastalıkların ABD'nin toplumsal istikrarını ve bu yüzyılın sonunda yaşadığı endüstriyel ve ekonomik büyümeyi sekteye uğratacak bir hal almaya başlaması, toplumu yeniden yapılandırmadan yoksulların sağlık koşullarını iyileştirecek bir sağlık reformunu kaçınılmaz kılmaktaydı. Bu yöndeki gelişmelerinden biri, Maliye Bakanlığına bağlı olan Deniz Hastanesi İdaresi'nin yetki ve sorumlulukları genişletilerek 1902'de Halk Sağlı̆̆ ve Deniz Hastanesi İdaresi'ne, 1912'de de Halk Sağlığı İdaresi dönüştürülmesidir (Luckett ve Gray, 1925: 133-134). Bu gelişme, ABD'de halk sağlığı sorunlarının giderek federal hükümetin temel görevlerinden biri olduğunun göstergesidir (Gascoigne, 2019: 127-128). Sağlık alanının bakanlık düzeyinde örgütlenmesi ise ancak 1953 yılında Başkan Eisenhower döneminde 'Sağlık, Eğitim ve Refah Bakanlığı'nın kurulması ile gerçekleşecektir (HHS, 2020). 19. yüzyılın sonlarındaki bir diğer gelişme ise birçok eyaleti etkisi altına alan sıtma, kancalı kurt, sarıhumma gibi tropikal bulaşıcı hastalıkların halk sağlığı programları ile tedavi edilebilmesi için Rockefeller Sağlık Komisyonu (Rockefeller Sanitary Commission) kurulması ve nüfusa bunun için tıbbi eğitim verilmesidir. Özellikle ABD'nin güney eyaletlerinde yürütülen bölgesel kampanyalarda elde edilen başarılar neticesinde, 1913 yılında Rockefeller Vakfi kurularak, Vakıf halk sağlığına ulusal ve uluslararası ölçekte yatırım yapmaya başlamıştır (Küçük, 2018b: 90-91).

Hızlı sanayileşme ve kentleşmenin ortaya çıkardığı kentsel sefalete ve hastalıklara rağmen, 18. ve 19. yüzyılda ABD'de sağlık politikaları yukarıda belirtildiği gibi bireysel gönüllülük, misyonerlerin gayreti ve askeri düşünce sistematiği ekseninde bir gelişim göstermiştir. Bununla 
birlikte, özellikle salgın hastalıkların kontrolünde Amerikan bireyciliğine karşı kolektivizm düşüncesinin ön plana çıkması, çıkar odaklı bir siyaset yerine teknolojik gereksinimlere dayalı bir politikanın benimsenmesine ve dolayısıyla halk sağlığında merkezi (federal) yönetim düzeyinde adımlar atılmasına olanak sağlamıştır. Nitekim Robert Higgs' in "Krizler ve Leviathan" (1987: 18) adlı kitabında büyük krizlerin (dünya savaşları, 1929 Ekonomik Buhranı gibi ekonomik krizler, isyanlar vb.) minimal devlet anlayışına sahip ABD'de merkezi yönetimin iktidarının genişlemesine yol açtı̆̆ varsayımından yola çıkılarak, önemli çevresel dışsallıklara sahip salgınların da bu kategoriye dâhil edilebileceği ileri sürülebilir.

Günümüzde mevcut koronavirüs krizi de ABD'de federal yönetimler ile eyalet yönetimleri arasındaki bu tarihsel tartışmayı yeniden alevlendirmiştir. Somin (2020), ABD'nin kuruluşundan bu yana halk sağllğ 1 ve karantina düzenlemelerinde esas sorumluluğun eyaletlerde olduğuna ve federal yönetime nazaran tarihsel olarak (1918-19 grip salgını dâhil) eyaletlerin ve yerel yönetimlerin bulaşıcı hastalıkların yayılmasına karşı mücadelede başlıca aktör olduğuna dikkat çekerken, buna karşın Zheng (2020) eyaletlerin koronavirüse karşı tek başına savaşamayacağını, federal yönetimin gerekli adımları atması gerektiğini ısrarla vurgulamaktadır. Bu çatışma siyasal ve sosyo-kültürel etmenlere bağlı olmakla birlikte, halk sağlığı yönetimi ile modern devlet arasındaki ilişkinin çok boyutlu doğasına ş̧ık tutmaktadır.

\section{Türkiye'de Sıhhiye Teşkilatının Kuruluşunda Salgınlar}

Diğer ülkelerde olduğu gibi hem 19. yüzyıl Osmanlı Devletinde hem de Erken Cumhuriyet Döneminde devletin modernleşme ve merkezileşme çabalarını harekete geçirici güçlerinden biri de bulaşıcı ve salgın hastalıklarla mücadele politikası olmuştur. Kolera ve veba başta olmak üzere bulaşıcı hastalıkların yayılma ve geçiş noktaları üzerinde bulunan Anadolu coğrafyasında doğal olarak salgınlar, merkezi sağlık teşkilatlarının kuruluşunu tetiklemiştir.

\section{Tanzimat Dönemi Osmanlı Merkezileşmesi ve Salgınların Etkisi}

Tarih boyunca veba, kolera, çiçek, cüzzam gibi birçok salgın hastalığa maruz kalan Osmanlı Devletinde, 1705-1837 yılları arasında sadece vebadan Selanik, İstanbul ve İzmir'de en az 600 bin kişi yaşamını yitirmiştir (Panzac, 1997: 182-183). Osmanlı Devletinde karantina ilk defa tedbir niteliğinde olarak 1823 yılında Rusya'da hüküm süren kolera münasebetiyle bu ülkeden Osmanlı limanlarına gelen ticaret gemilerine uygulanmıştır. 1831 yılında ise Yakın Doğu'dan gelen kolera salgını nedeniyle İstanbul'da, 1835 yılında da Çanakkale'de karantina uygulamasına gidilmiştir (Sarıyldız, 1994: 331-334; Berkes, 2003: 188; Aydın, 2002: 9-10). Bu uygulamalara Osmanlı Devleti'nin özellikle İstanbul üzerinden diğer Avrupa ülkeleri ile gelişmeye başlayan kapitalist üretim ilişkilerinin etkisinin yol açtığı söylenebilir. Böylece devletin merkezi sağlık teşkilatı, iç ve dış dinamiklere bağlı olarak şekillenmeye başlamıştır.

1831'de görülen kolera salgının tetiklediği Sihhiye (Karantina) Nezareti ile ilgili ilk kurumlaşma çabaları, Tural'a göre (2009: 157-158) Selim Satı, Mehmet Esad ve Abdülhak Molla Efendiler ile 1835 yılında Takvimi Vekayi'de kaleme alınan tedbirler silsilesi ile başlamıştır. Daha sonra II. Mahmut'un emriyle karantina uygulayan ülkelerden getirilen uzmanların yardımı ile karantina uygulamalarının düzenlenmesi amaciyla 1838 'de Hariciye Nezaretine bağlı "Karantina Meclisi" (diğer adıyla Meclis-i Umûr-1 Sihhiye) kurulmuştur. Karantina Meclisi ile ilgili düzenleme yapmak üzere Avusturya'dan uzman talep edilmesi (Sarıyıldı, 1994: 347-348), Avusturya'nın kameralizm ve medikal polis düzenlemeleri sonucu elde ettiği başarının bir etkisi olarak yorumlanabilir.

Salgın hastalıklara bağlı olarak gelişme gösteren diğer bir kurumlaşma örneği ise 1827 yılında ilk tıp okulu olan 'Tıphane-i Amire'nin açılmasıdır. Osmanlı'daki merkezileşme ve modernleşme çabalarının asıl itici gücü olan 'merkezi, modern bir ordu'nun meydana getirilmesi, mali ve bürokratik bir yapıyı gerektirdiği gibi hastalıklardan arındırılıp güçlü olmasını da 
gerektiriyordu (Önen ve Reyhan, 2011: 27-31). Ordunun sağlık ihtiyaçlarının karşılanması ihtiyacı da böyle bir okulun açılmasını zorunlu kılmıştır. Buna ilave olarak askeri tıp okulunun açılma nedenleri arasında Niyazi Berkes (2003: 185) yabancı hekim sayısının kontrolsüz artışını ve Yakın Doğuya yayılan kolera salgınlarını da etken olarak göstermektedir. Dolayısıyla sadece Tanzimat hareketi ile birlikte merkeziyetçiliği arttırma ve idari kurumları modernleştirme girişimlerinin başlamadığı, bunun öncüllerinin olduğu ileri sürülebilir. Nitekim Süheyl Ünver (1940: 959-962) Tanzimat öncesinde Tiphane-i Amire'nin açılması, Avrupa'dan hocalar ve hekimler getirilmesi, Avrupa'ya öğrenci gönderilmesi, Karantina Meclisi'nin kurulması, bulaşıcı hastalıklar hakkında nizamnameler yayımlanması, Tanzimat'la birlikte; karantina teşkilatının geliştirilmesi, ölüm istatistiklerinin düzenli olarak toplanmaya başlanması, Türkçe tıp eğitimine önem verilmesini merkeziyetçi karakterdeki yenilikler olarak değerlendirmektedir. Osmanlı döneminde Tanzimat sonrası taşra yönetimi üzerinde merkeziyetçi düzenlemeleri tamamlayıcı nitelikte sağlı alanında da yeniden yapılanmaya gidilmiştir. 1866 yılında ilk sivil tıp okulu olan "Mektebi Tıbbiye-i Mülkiye"nin açılması, 1871'de "İdare-i Umumiye Tıbbiye Nizamnamesi" ile 'memleket tabibi' adı altında il ve ilçelerde hekimler ile sıhhiye müfettişlerinin görevlendirilmesi (Aydın, 2002: 13-20) vilayetlerde hıfzıssıhha çalışmalarını kurumsallaştırmaya ve güçlendirmeye yönelik merkezileşme sürecinin bileşenleridir. Aynı şekilde hac zamanlarında yaşanabilecek salgın hastalıklara karşı önceden önlem alınması amacıyla 1910 yılında Hicaz Umûr-ı Sihhiyesi Meclisi kurulması (Tural, 2009: 159-160), 1913'te “Vilayet İdare-i Sihhiye Nizamnamesi” ile her ilde "sağlık müdürlüğü" ve "sıhhiye meclisi" oluşturulması, 1914 yılında yayımlanan nizamname ile de ülkede ilk defa bulaşıcı hastalıkların ihbarı zorunlu hale getirilmesi (Sıhhat ve İçtimai Muavenet Vekâleti, 1933: 17) merkezi yönetimin denetim ve kontrol işlevini güçlendirmeye yönelik düzenlemelerdir. Bu yönüyle yerel örgütlenme, Osmanlı Devleti'nin merkezileşme sürecinin tamamlanmasında kritik bir rol oynamıştır.

\section{Erken Cumhuriyet Döneminde Halk Sağlığının Kurumsallaşması}

1920 yılında TBMM kurulur kurulmaz yapılan ilk işlerden biri olan Sağlık Bakanlığı'nın kurulması, tıpkı Otuz Yı1 Savaşları sonrası Almanya'da kameralizmi ortaya çıkaran koşullarla benzer şekilde kamu refahı ve sağlığı sorununu gündeme taşımışıtır. Savaş ve salgın hastalıkların nüfus üzerinde yarattığı yıkımın üstesinden gelmek amacıyla sağlık alanında izlenecek politikanın amacını Atatürk 1922 senesinde "milletimizin sağlığının korunması ve geliştirilmesi, ölümün azaltılması, nüfusun arttırılması, bulaşıcı ve salgın hastalıkların etkisiz hale getirilmesi, bu suretle millet bireylerinin dinç ve çalışmaya yetenekli bir halde sağlıklı bedenler olarak yetiştirilmesini sağlamak" (TBMM Zabıt Ceridesi, 1922: 4) olarak özetlemektedir. Bu bağlamda Cumhuriyetin ilk yıllarında hıfzıssıhha reform hareketleri, toplumsal düzenin sağlanması ve ulus devlete özgü merkezileşmenin ortaya çıkışında önemli bir rol üstlenmiştir.

Sağlık Bakanlığı'nın ilk 10 yılı içinde en önem verdiği politika olan halk sağlı̆̆ına yönelik kurumsallaşma çabasında, bulaşıcı ve salgın hastalıklarla etkin mücadele en önemli bileşeni oluşturmuştur. Devletin salgın hastalıklarla mücadele politikası için bilgi toplama ve yöntem geliştirme amacıyla ülkedeki her yöre ayrı ayrı etüt ettirilmiştir. "Türkiye'nin Sihhî-i İçtimaı Coğrafyası" adıyla 1922-1938 yılları arasında yayımlanan çalışmalar ile Sinop, Ankara, Isparta, Gelibolu, Kırşehir, Urfa, Niğde gibi 19 vilayetin fiziki ve sosyo-ekonomik özelliklerinin yanı sıra başta frengi, sıtma, verem, trahom, çiçek gibi salgın hastalıkların dönemsel durumu resmedilmiştir (Esen, 2017: 73-90). 1921 yılında Frenginin Men ve Tahdidi Sirayeti Hakkında Kanun ile 1926 yılında Sitma Mücadelesi Kanunu çıkarılarak bulaşıcı hastalıklarla mücadelede düzenlemeler yapılmıştır. Lozan Anlaşması sonrası 1924 yılında Sağlık Bakanlığına bağlı 'Hudut ve Sahiller Sağlık Genel Müdürlüğü' kurulması ile karantina uygulamaları kapitülasyon niteliğinden arındırılmıştır. 1928 yılında 1267 sayılı kanunla bulaşıcı ve salgın hastalıklara karşı aşı ve serum geliştirmek, ilaç üretmek, laboratuvar testleri yapmak ve halk sağlığı alanında personel yetiştirmek üzere T.C. Merkez Hifzıssıhha Müessesesi kurulmuştur. Halk sağlığı alanındaki bu sistematik girişimlerin bir sonucu olarak da devletin genel sağlık politikası 1930 yılında kabul edilen 1593 sayılı 
Umumi Hıfzıssıhha Kanunu ile belirlenmiştir. Doğal bedenin, siyasal bedenin yönetim ve gözetim sistemine dâhil edildiği bu düzenleme ile bütün devlet örgütlenmesine sağlıkla ilgili roller verilerek, ulusun sağlığını korumanın devletin temel görevi olduğu kabul edilmiştir (Küçük, 2018a: 102-103). 309 maddeden oluşan ve halen yürürlükte olan bu geniş kapsamlı kanunun ikinci bölümü 'bulaşıc1 ve salgın hastalıklarla mücadele' (29-127 maddeler) konusuna (kanunun yaklaşık 3'te biri) ayrılmıştır. Halk sağlığı alanındaki bütün bu gelişmeler, Cumhuriyetin kurucu unsurlarına siyasal ve yönetsel merkezileşmenin ön koşullarının yaratılmasında elverişli bir ortam hazırlamıştır.

Günümüzde Umumi Hıfzıssıhha Kanununa dayanılarak koronavirüs salgınının/bulaşın toplum sağlığı ve kamu düzeni açısından oluşturduğu riski yönetme, sosyal izolasyonu temin etme, sosyal mesafeyi koruma ve yayılım hızını kontrol altında tutma amacıyla birçok tedbir kararı alınarak uygulamaya geçirilmektedir. Bu kanun, İçişleri Bakanlığı tarafindan yayımlanan 'sokağa çıkma kısıtlaması', 'geçici olarak meslek mensuplarının görevlerini yapmalarının engellenmesi', 'toplantıların sınırlandırılması ve yasaklanması', 'yasaklara aykırı hareket eden işyerleri ve vatandaşlara cezai müeyyideler uygulanması' gibi tedbirlerinin de dayanağıdır. Nitekim İçişleri Bakanlığı genelgelerinde Umumi Hıfzıssıhha Kanunu'nun 27 ve 72 nci maddelerine atıfta bulunarak kısıtlayıcı tedbirleri uygulamaktadır. Hatta günümüzde oluşturulan COVID-19 Bilimsel Danışma Kurulu'nun fonksiyonel kökeninin Umumi Hıfzıssıhha Kanunu ile oluşturulan ve 2011 yılında mülga edilen Yüksek Sağlık Şurası'na kadar uzandığı ileri sürülebilir. Dolayısıyla 90 yıldır yürürlükte olan bu kanunun hala daha güncelliğini koruması ve salgınla mücadelede öncü rol oynaması, Türkiye'de halk sağlığının sağlam bir zemine oturtulduğunun ispatı olarak gösterilebilir.

\section{Sonuç}

Antik dönemlere kadar uzanan tarihsel uğrak noktalarına sahip olan salgın hastalıklar, 17. yüzyıldan sonra kapitalist gelişme ile hızlı sanayileşme ve kentleşmenin ortaya çıkardığı toplumsal sorunlarla artmaya başlamıştır. Salgın hastalık tehdidi, kapitalizmin pazarın bütünlügüne dayalı merkezileşme eğilimi (sonrasında küreselleşmeye evrilen) ile yönetimde merkezileşmenin eşanlı ve eşgüdümlü bir biçimde hareket etmesinin bir unsuru olmuştur. Modern ulus-devlet de kolera, tifo ve veba gibi salgın dönemlerinde virüs-bakteri gibi 'görünmez düşmanlara' karşı mücadelenin temel aktörü olarak ortaya çıkmış ve gelişme göstermiştir. Ulus-devletin ana karakteristiklerinden olan merkezileşmenin ortaya çıkışı da ülkelere göre farklılık gösterse de nüfusun sağlığı bu sürecin bir katalizörü olmuştur. Bundan dolayı, gerek Kameralizm ve medikal polis eksenli Alman merkezileşmesinde, gerekse Viktoryan dönemi İngiliz merkezileşmesinde, federalist anti-federalist tartışmalarla biçimlenen Amerikan merkezileşmesinde ve Tanzimat sonrası Osmanlı Devleti ile Erken Cumhuriyet döneminde devletin örgütlenme biçiminde ve bürokratik yapılanmasında sağlık alanının kurumsallaşması başat rol oynamıştır. Üstelik neoliberal politik düşünceye dayalı atomistik bireycilik ve minimal devlet anlayışının hâkim olduğu ABD ve İngiltere gibi devletlerde salgın dönemlerinde kolektivist yönelimlerin yaşanması dikkat çekicidir. Gerçekten de, günümüzde koronavirüs salgınının yarattığı sağlık eksenli 'ulusal güvenlik' sorununun, 17. yüzyılda İngiliz filozof Thomas Hobbes'un 'Leviathan' dediği şeyi yeniden uyandırdığı dahi öne sürülebilir. Nitekim bu salgında görüldügüü üzere ne uluslararası örgütlerin ne de küresel şirketlerin virüsle mücadelede pek bir etkisi gerçekleşmemiştir. Günümüzde devlet, virüsle mücadelede dijital teknolojilerin verdiği imkânlarla (akıllı telefonlar, yapay zekâ destekli yazılımlar, dronlarla ateş ölçme, veri analitiği uygulamaları gibi) toplumsal kontrol ve gözetim işlevini her zamankinden fazla kullanabilecek araçlara sahiptir. Salgın gibi kriz dönemlerinde bu araçların yaygın kullanımı da merkezileşmeyi güçlendirmeye hizmet etmektedir.

Koronavirüs salgını 'ulusların zenginliğgi'nin, aslında 'ulusların sağlığı' olduğu gerçeğini bir kez daha kanıtlamıştır. Modern devletin ortaya çıkması ile özellikle Kameralist düşünürlerin savunduğu sağlık harcamalarının ve koruyucu sağlık hizmetlerinin ekonomik büyümeye katkıda bulunan bir yatırım olduğu görüşü bugün hala geçerliliğini korumaktadır. Sağlığa yatırım bir maliyet 
unsuru değil, kamusal refahın bir önkoşulu olarak düşünülmelidir. Bu bağlamda koronavirüs salgını, yerelleştirme ve piyasalaştırma politikaları ile birlikte sağlık alanında neoliberal reform paketleri ile devletin mali krizi gerekçe gösterilerek maliyet-azaltıcı bir tedbir olarak sağlık harcamalarının azaltılması politikasını yeniden tartışmaya açmıştır. Dolayısıyla koronavirüs salgını, yeni dönemde devletlerin halk sağlığına bakış açısının değişmesine, sağlık alanında başta ilaç, aşı, koruyucu malzeme, tıbbi cihaz olmak üzere Ar-ge odaklı sosyal yatırım harcamalarının artmasına vesile olabilecektir. Bu eğilimin bir uzantısı olarak sosyal yatırım işlevlerinin tekelleşmesi talebinin ise yeni tür bir merkezileşmeye yol açabileceği ileri sürülebilir.

\section{Kaynakça}

Akbulut, Ö. (2007). Küreselleşme, Ulus-Devlet ve Kamu Yönetimi, TODAİE Yayınları.

Aktel, M, U. Kerman, Y. Altan ve F. Güven (2015). "Kameralizmi Anlama Çabası”, Mehmet Akif Ersoy Üniversitesi Sosyal Bilimler Enstitüsü Dergisi, 7 (12): 83-98.

Aydın, E. (2002). Türkiye'de Sağglk Teşkilatlanması Tarihi, Naturel Yayıncılık.

Bashford, A. and C. Hooker (2001). Contagion: historical and cultural studies, New Fetter Lane, Routledge.

Backhaus, U. (2009). “Johann Heinrich Gottlob von Justi (1717-1771): Health as Part of a State's Capital Endowment", in The Beginnings of Political Economy: Johann Heinrich Gottlob von Justi, Ed.Jurgen Georg Backhaus, European Heritage in Economics and the Social Sciences, Vol.7, Springer, 171-195.

Berkes, N. (2003). Türkiye'de Çağdaşlaşma, Dördüncü Baskı, Yapı Kredi Yayınları.

Carroll, PE. (2002). "Medical Police and the History of Public Health", Medical History, 46: 461494.

Esen, A. (2017). "Sıhhî-İ İctimâî Coğrafya Kitaplarına Göre İç Anadolu'da Görülen Salgın Hastalıklar (1922-1926)", Ankara Üniversitesi Türk İnklâp Tarihi Enstitüsü Atatürk Yolu Dergisi, 60; 73-90.

Evans, RJ. (1990). Death in Hamburg: Society and Politics in the Cholera Years 1830-1910, Penguin Books.

Foucault, M. (1973). The Birth of the Clinic: An Archaeology of Medical Perception, trans. Alan Sheridan, Routledge.

Foucault, M. (1990). The History of Sexuality. Volume 1: An Introduction (London, Vintage Books; first English translation 1978).

Gascoigne, J. (2019). Science and the State: From the Scientific Revolution to World War II (New Approaches to the History of Science and Medicine). Cambridge University Press.

Hamlin, C. (1998). Public health and social justice in the age of Chadwick: Britain 1800-1854, Cambridge University Press.

Hays, JN. (2005). Epidemics and pandemics: their impacts on human history, Abc-Clio.

Higgs, R. (1987). Crisis and Leviathan: Critical Episodes in the Growth of American Government, Oxford University Press.

HHS (2020), HHS Historical Highlights, 01.01.2020, https://www.hhs.gov/about/historicalhighlights/index.html 
https://www.hurriyet.com.tr/dunya/brezilya-devlet-baskani-bolsonaro-kovid-19u-basit-bir-gripolarak-nitelendirdi-41478014 (17.04.2020)

Küçük, A. (2018a). Kapitalizm, Devlet, Sağllk ve Türkiye, Akademisyen Kitabevi.

Küçük, A. (2018b). "Hayırsever Kapitalizmi ve Erken Cumhuriyet Döneminde Sağlık Hizmetlerinin Örgütlenmesi: Rockefeller Vakfının Rolü”, Amme İdaresi Dergisi, 51 (2): 87-116.

Lawes, K. (2000). Paternalism and Politics: The Revival of Paternalism in Early Nineteenth-Century Britain, Macmillan.

Lister, J. (2008). Sağlık Politikası Reformu: Yanlış Yolda mı Gidiyoruz? Çev. Melis İnan vd., İnsev Yayınları.

Lizardo, PG. (2020). The Case for Centralization in Times of COVID-19, McGill Journal of Political Studies, April 23, 2020, https://mjps.ssmu.ca/2020/04/23/the-case-for-centralization-intimes-of-covid-19/

Longrigg, J. (1992). "Epidemic, ideas and classical Athenian society", in Epidemics and Ideas. Essays in the Historical Perceptions of Pestilence, T.Ranger and P.Slack (eds), Cambridge University Press, 21-44.

Luckett, GP ve HF. Gray (1925), Sihhat-i Umumiye İdaresi Esasatı-Halk Sağlı̆̆ Yönetim Esaslarl, İkinci Basım, Osmanlıcadan Çev. Sağlık Bakanlığı.

McLean, D. (2006). Public Health and Politics in the Age of Reform: Cholera, the State and the Royal Navy in Victorian Britain, Tauris.

McNeill, WH. (1976). Plagues and Peoples, Garden City, Ancror Books.

Navarro, V. (2020). The Consequences of Neoliberalism in the Current Pandemic, International Journal of Health Services, 50 (3): 271-275.

Neocleous, M. (2000). The Fabrication of Social Order: A Critical Theory of Police Power, Pluto Press.

Neocleous, M. (2014). Devleti Tahayyül Etmek, Çev. Akın Sarı, Notabene Yayınları.

New York Times (2020). Europe's museums begin reopening, cautiously, with new rules. 13/05/2020, www.nytimes.com/2020/05/13/world/coronavirus-world-news-updates.html

Önen, N. ve C. Reyhan (2011). Mülkten Ülkeye: Türkiye'de Taşra İdaresinin Dönüşümü (18391929), İletişim Yayınevi.

Peters, MA. (2020). "The disorder of things: Quarantine unemployment, the decline of neoliberalism, and the Covid-19 lockdown crash", Educational Philosophy and Theory, http://dx.doi.org/10.1080/00131857.2020.1759190

Panzac, D. (1997). Osmanlı İmparatorluğu'nda Veba 1700-1850, Tarih Vakfi Yurt Yayınları.

Pullan, B. (1992). "Plague and perceptions of the poor in early modern Italy", in Epidemics and Ideas. Essays in the Historical Perceptions of Pestilence, T.Ranger and P.Slack (eds), Cambridge: Cambridge University Press, 101-124.

Porter, D. (1999). Health, Civilization and the State: A history of public health from ancient to modern times, Routledge.

Ranger, T. and P. Slack (eds) (1992). Epidemics and Ideas. Essays in the Historical Perceptions of Pestilence, Cambridge University Press. 
Reis Gazi Mustafa Kemal Paşa'nın Meclis Açılış Konuşması, TBMM Zabıt Ceridesi, Yasama Yılı 3 , Cilt 18, 1 Mart 1922 Çarşamba, Dönem 1, Oturum 1, s.4.

Rosen, G. (1953). "Cameralism and the Concept of Medical Police", Bulletin of the History of Medicine, 27 (1): 21-42.

Sarıyıldız, G. (1989). Hicaz Karantina Teşkilatı (1865-1914), [Yayımlanmamış doktora tezi], İstanbul Üniversitesi Sosyal Bilimler Enstitüsü.

Sarıyıldız, G. (1994). “Karantina Meclisi'nin Kuruluşu ve Faaliyetleri”, Belleten, LVIII (222): 329376.

Sechel, D. (2003). "The Influence of Cameralism and Enlightenment upon the Sanitary Policy Promoted by the Habsburgs in Transylvania (1740-1800)", Revista Bistriţei, 17, 159-170.

Sihhat ve İçtimai Muavenet Vekâleti (1933). "Vekâletin 10 Yıllık Mesaisi”, Sihhiye Mecmuası Fevkalade Nüshası, (29 Ekim) Sihhat ve İçtimai Muavenet Vekâleti.

Small, WA. [2001 (1909)], The Cameralists: The Pioneers of German Social Polity, Kitchener: Botoche Books.

Somin, I. (2020). Federalism and the Coronavirus Crisis, The Volokh Conspiracy, 31 March 2020, https://reason.com/2020/03/31/federalism-and-the-coronavirus-crisis/

Timor, AN. (1996), “Tıbbi Coğrafya: Kapsamı ve Amacı”, İstanbul Üniversitesi Coğrafya Dergisi, 4: 303-319.

Tural, E. (2009). Osmanlı Imparatorluğu ve Avrupa'da Devlet Sistemi, IQ Kültür Sanat Yayıncılık.

Ünver, A.S. (1940). “Osmanlı Tababeti ve Tanzimat Hakkında Yeni Notlar”, Tanzimat I: Yüzüncü yıldönümü münasebet ile, Ankara: Maarif Vekâleti, 933-966.

Wakefield, A. (2009). The Disordered Police State: German Cameralism as Science and Practice, The University of Chicago Press.

Weisz, G. (1986). "Constructing the Medical Elite in France: The Creation of the Royal Academy of Medicine 1814-20", Medical History, 30: 419-443.

Weible, C.M., Nohrstedt, D., Cairney, P. et al. (2020). "COVID-19 and the policy sciences: initial reactions and perspectives", Policy Sciences, 53: 225-241.

Zheng, F. (2020). Coronavirus: States cannot fight coronavirus alone. The federal government must step up, 21 March 2020, https://fortune.com/author/fanyin-zheng/ 